\title{
FLORES RUIZ, Eva. María y OLMEDO SÁNCHEZ, Yolanda Victoria. (eds.): Entre plumas y pinceles. Imágenes femeninas en la literatura y la pintura (1800-1950), Madrid, Sial/Trivium, 2020.
}

MINERVA PARRA PERALBO

Universidad Internacional de La Rioja (UNIR)

Universidad Francisco de Vitoria (UFV)

La idea de realizar una obra como ésta es más que pertinente, donde se refleja cómo la figura de la mujer ha sido "modelada culturalmente" a través de las obras creadas por figuras masculinas, rastreando la pintura y la literatura desde 1800 al 1950.

El texto se encuentra dividido en siete capítulos, escritos cada uno de ellos por las editoras de la obra y cinco autores especialistas en las expresiones artísticas pictórica y literaria; de ahí el título del libro, a lo largo de los cuales se fusiona dos líneas a través de la figura femenina: la figura femenina como alegoría en las expresiones artísticas y la figura femenina como autora en estas mismas. Una dualidad, la mujer como mero objeto, inspiración de temáticas y alegorías de grandes virtudes, frente a la figura "femenina del pecado", dejando, con ello, limitado cuáles debieran de ser los puestos que las mujeres debían de ocupar, construyendo una "trampa" para que la mujer no usurpara terreno intelectual, sino que tomara la posición de "ángel

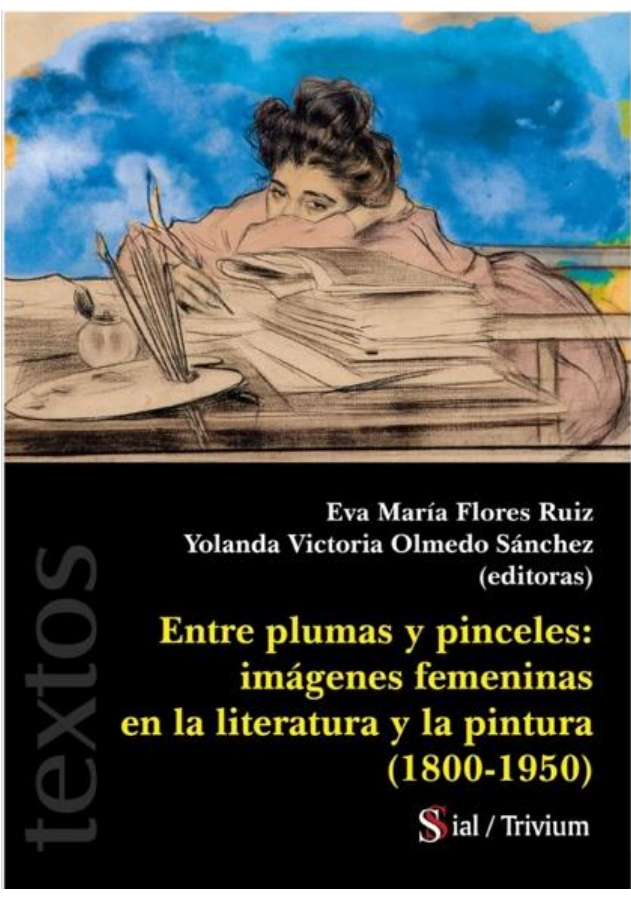
del hogar".

No hay que olvidar que hoy tenemos otra cultura y que no podemos juzgar con nuestros ojos situaciones pasadas. Sin embargo, el libro no toma una posición de juez, sino que expone situaciones y las consecuencias que ello llevó en cada situación. Cada capítulo revela cómo las representaciones de la figura femenina es el reflejo de cómo se consideraba a la fémina como persona, una relación que se retroalimenta: la representación visual de la figura femenina y la representación de los modos que una (buena) mujer debería de seguir.

A lo largo de los capítulos se refleja continuamente este hecho y de cómo el hombre desde su condición de autor y creador ha condicionado el desarrollo de la mujer de manera equitativa; por un lado, bajo una visión paternalista, cuya función era de "proteger" a la mujer, un ser "débil, delicado". Por otro, se refleja otra figura de mujer, el lado negativo, maligno, el de aquella mujer que rebasa esos límites establecidos y que conducen a la virtud femenina, convirtiéndose en la "mujer fatal, decadente". 
Con la lectura del libro, con el avance de cada capítulo, vemos la transformación de la figura femenina entre pintura y literatura, siendo objeto creado y siendo creador. Desde la representación de la mujer como alegoría del "ángel del hogar", con una posición pasiva en cuanto a la actividad intelectual; a la mujer independiente, "desviada" de lo esperado, de los cánones "consensuados" pintados y escritos. De la mujer que se atreve a pintar, pero que no es tratada en serio y por tanto no se le reconocerá atributos iconográficos que sus colegas masculinos sí disfrutan; a aquellas mujeres humildes y trabajadores que son "satirizadas" descritas e imaginadas en la literatura, describiendo la conciencia de una época. Desde la prostituta, a la mujer pintora y a la mujer escritora del siglo XIX.

El texto consigue el objetivo de demostrar evidencias de relación entre la pintura y la literatura, desde la figura femenina como creación y como creador, entre el período de 1800 a 1950. Sin lugar a duda, es un trabajo de coordinación fantástico, con un minucioso estudio por parte de cada uno de los autores. 